\title{
Elements of Delays in Construction Management of DPWH Aurora District Engineering Office
}

\author{
Pantalunan, Carlito H. ${ }^{1}$, Renomeron, Christine L. ${ }^{2}$, De Castro, Pinky Sarah A. ${ }^{3}$, Manzon, Rick Donald ${ }^{4}$, \\ Jocson, Joefil C. ${ }^{5}$
}

\begin{abstract}
The Department of Public Works and Highways Department is the engineering and construction arm of the government, whose primary role is to constantly innovate in order to meet the best standards of competence when building public works and highways and to utilize infrastructure projects in an effective and efficient manner. While project implementation is closely monitored, unexpected complications can occasionally cause project delays. Delays and associated costs and disputes result in lawsuits, claims, and, in the worst-case scenario, project termination, all of which have a significant impact on the project itself. To acquire knowledge and understanding of the Elements of Delays in the Construction of the DPWH Aurora District Engineering Office (DPWH-ADEO).This was accomplished through an evaluation of documents obtained from DPWH-ADEO, as well as a survey of DPWH-ADEO managers, project engineers, and contractor's representatives using an adapted questionnaire. Three of the primary reasons for suspension in 2019-2020, according to information obtained, were weather-related events, the COVID-19 virus, and the pending completion of another phase. A survey questionnaire revealed that the three most common problems encountered in projects are rain, pandemic-related delays, and order changes. These findings could be used to develop an effective and appropriate construction management strategy for avoiding or, in the event of delays, mitigating DPWH Aurora District Engineering Office delays.
\end{abstract}

Keywords: Construction, Delay, DPWH

\section{INTRODUCTION}

Construction projects have numerous elements that may affect their successful implementation. Unpredictable issues and complications are unavoidable during the process. Some projects may exceed the contract schedule and experience delays, resulting in a slew of negative consequences for clients, consultants, and contractors.Construction delays are prevalent and recurring in poor countries, according to Toor and Ogunlana (2008), and the causes of these delays are similar. According to their research, delays in developing countries are caused by a lack of capital, technically inexperienced and less experienced local firms, an immature business climate, and challenges in legal and regulatory system. The key delay causes that contribute to project overruns, according to Hammadi and Nawab (2016), are related to the project owner's role, the contractor's involvement, funding, materials, and design documentation. Although several studies on delay issues such as financing and technical incompetence have been done, less focus has been placed on other variables that contribute to delays in government-funded infrastructure projects such as those handled by the DPWH-ADEO. The purpose of this paper is to address it and compare the results to those stated in previous research.

\section{RESEARCH METHODOLOGY}

A questionnaire was distributed in order to obtain important data for the study's goal. Quantitative questionnaires adapted from a study by Aedwin Regi Varghese and Shibi Varghese (2015) were used. The delay factors were enumerated and divided into five categories such as: financial related, design related, natural causes/external causes, management related and construction related. Questionnaires are then distributed to DPWH management staff, project engineers, and contractors via online Google forms.

The answers given by DPWH management, engineers and contractors were collected and analyzed as shown in Figure 3-1.

To assess the relative relevance of different causes, RII was calculated for each cause, with each calculation giving a different value depending on the cause. RII values were used to rank these factors.

The recorded data of completed projects from year 20192020 of DPWH ADEO was fetched and used to support and result of the ranked causes of delay. 


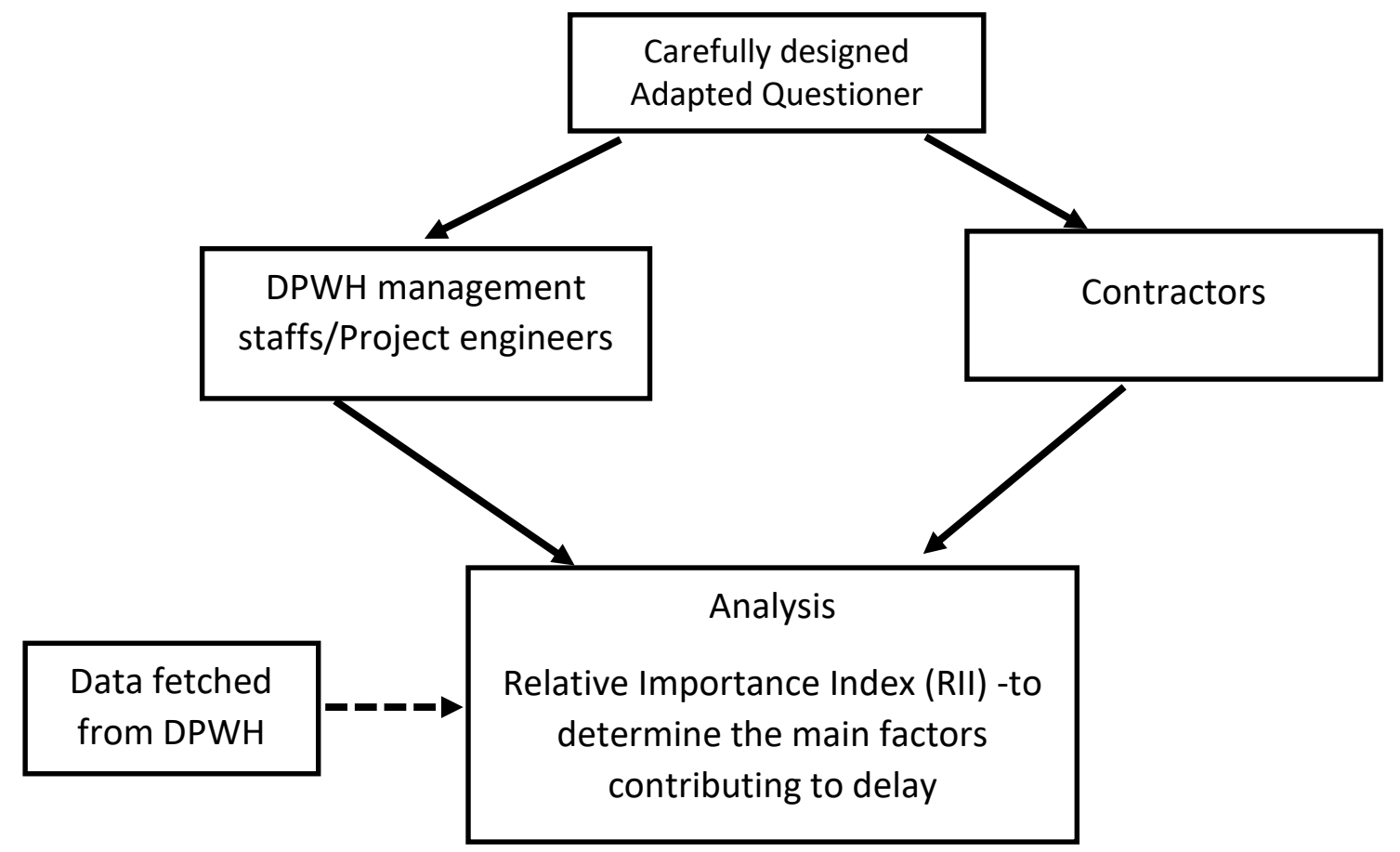

Figure 3-1. Flow of Data Collection and Analysis

\section{RESULTS AND DISCUSSION}

The data gathered from the records of DPWH-ADEO on their projects from 2019-2020, was being analyzed and found that there are 317 projects completed and 188 of that were encountered delays $(59.3 \%)$.
Of these 188 projects, 141 were due to the weather, 71 were due to the Covid-19 pandemic and 14 to the lack of materials in the area.

Table 4-1. Data on DPWH ADEO Projects 2019-2020

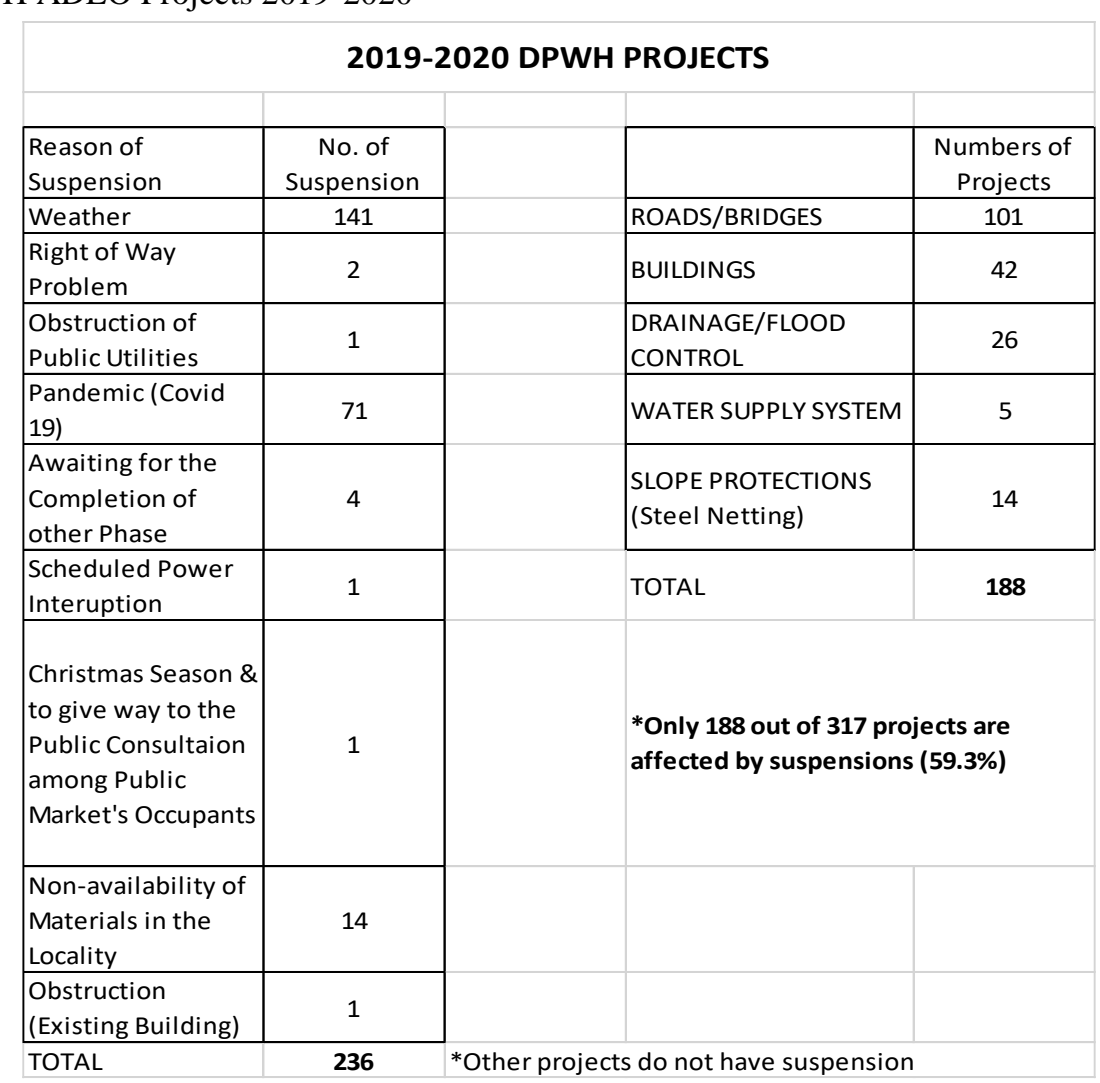

The findings of the analysis of quantitative data gathered using a survey questionnaire were presented as follows: 
A total number of 50 people responded to the survey questionnaires via google form online. Most of them were from contractors $(64 \%)$, the remaining were from DPWH-ADEO (36\%). All the respondents were involved in the projects of DPWH-ADEO from 2019-2020.

Table 4-2. Respondents work Position

\begin{tabular}{|c|c|c|c|}
\hline $\begin{array}{c}\text { Work } \\
\text { Position }\end{array}$ & $\begin{array}{c}\text { Engineer } \\
\text { (Contractor) }\end{array}$ & $\begin{array}{c}\text { Consultant } \\
\text { (DPWH } \\
\text { ADEO) }\end{array}$ & $\begin{array}{c}\text { Client/Client } \\
\text { Representative } \\
\text { (DPWH ADEO) }\end{array}$ \\
\hline Frequency & 32 & 14 & 4 \\
\hline Percentage & 64 & 28 & 8 \\
\hline
\end{tabular}

The majority of respondents belonged to $26-30$ years of age, (30\%), for $41-50$ years of age, $(32 \%)$ and $16 \%$ of the respondents were $>50$ years old.

Table 4-3. Classification of respondents by their age

\begin{tabular}{|c|c|c|c|c|c|}
\hline Age in Years & $\mathbf{2 6 - 3 0}$ & $\mathbf{3 1 - 3 5}$ & $\mathbf{3 6 - 4 0}$ & $\mathbf{4 1 - 5 0}$ & $>\mathbf{5 0}$ \\
\hline Frequency & 15 & 7 & 4 & 16 & 8 \\
\hline $\begin{array}{c}\text { Percentage } \\
(\%)\end{array}$ & 30 & 14 & 8 & 32 & 16 \\
\hline
\end{tabular}

The vast majority of respondents had less than 5 years of work experience (58\%), while $18 \%$ had over 11 years of experience.

Table 4-4. Respondents 'years of experience

\begin{tabular}{|c|c|c|c|c|}
\hline Experience in years & $<\mathbf{5}$ & $\mathbf{6 - 1 0}$ & $\mathbf{1 1 - 1 5}$ & $>\mathbf{1 5}$ \\
\hline Frequency & 29 & 12 & 6 & 3 \\
\hline Percentage (\%) & 58 & 24 & 12 & 6 \\
\hline
\end{tabular}

The answers to the surveys are used to figure out the root causes of delays. In order to determine the main reasons, the relatively large index, RII, was calculated for each cause. The causes were classified on the basis of RII. The causes of the delays in each of these five categories rank from the highest to the lowest level, as illustrated in figures 1 to 5 below.

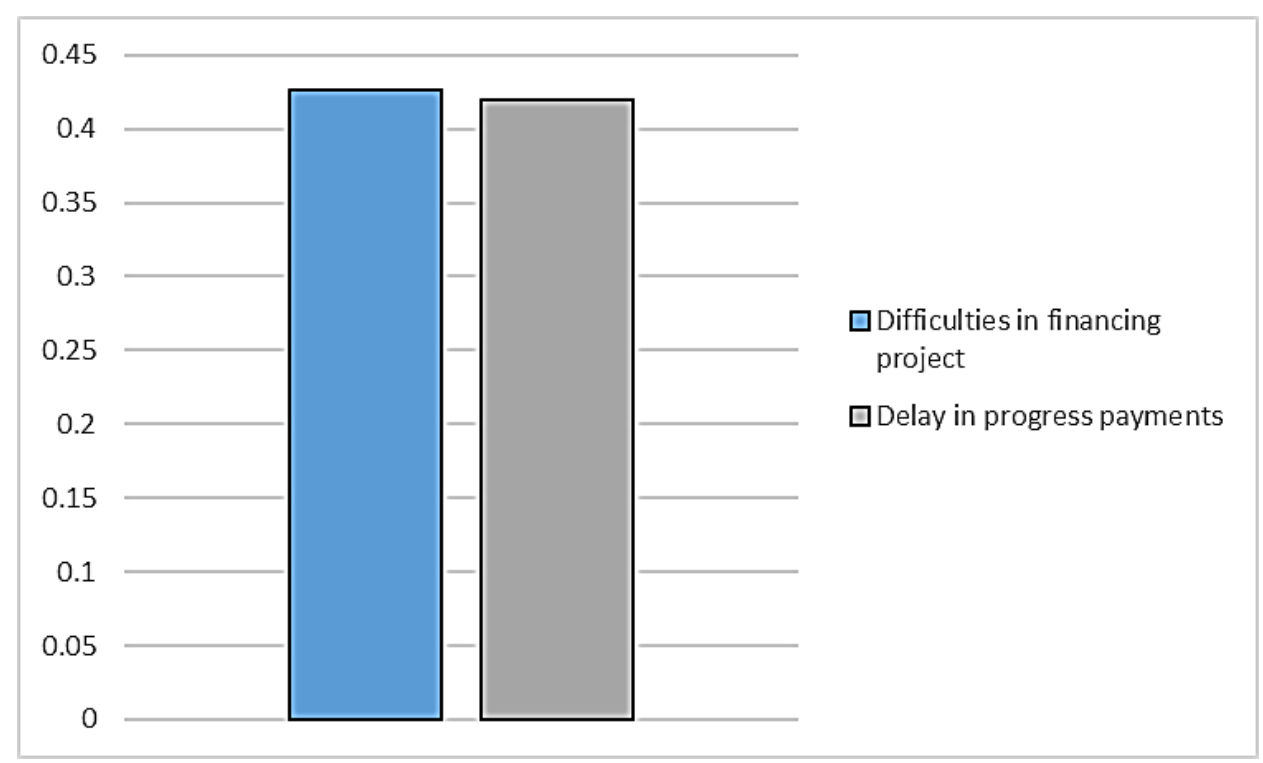

Figure 4-1. Financial-related Causes 
"Elements of Delays in Construction Management of DPWH Aurora District Engineering Office"

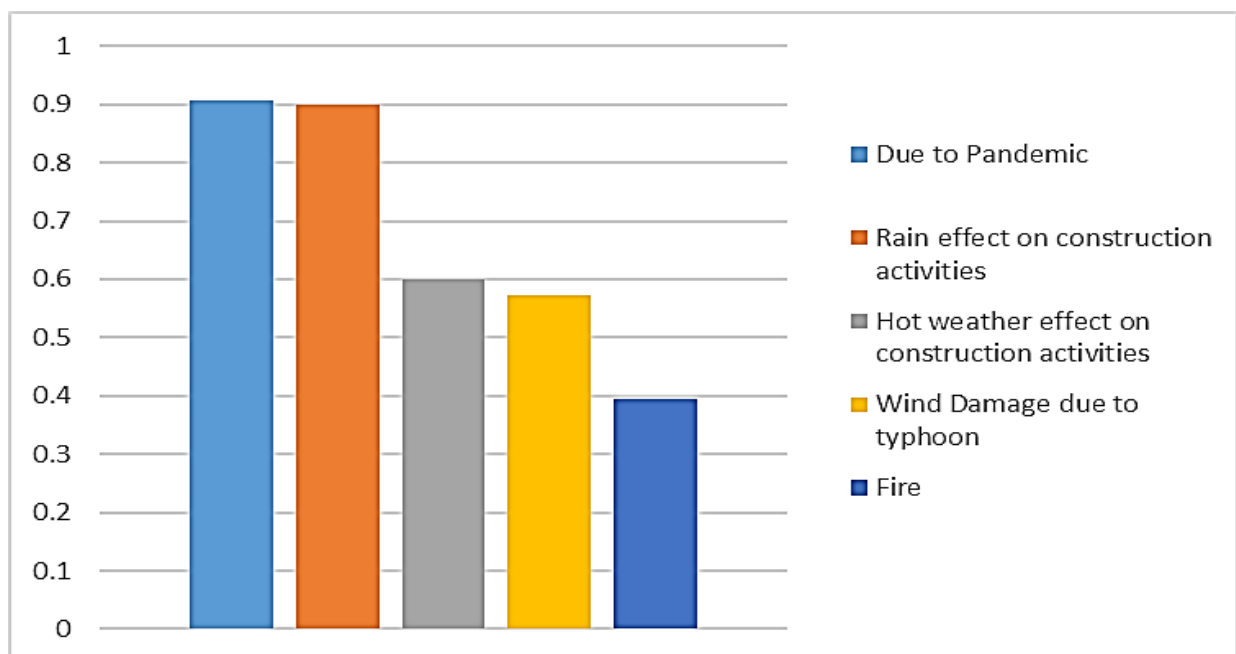

Figure 4-2. Design-related Causes

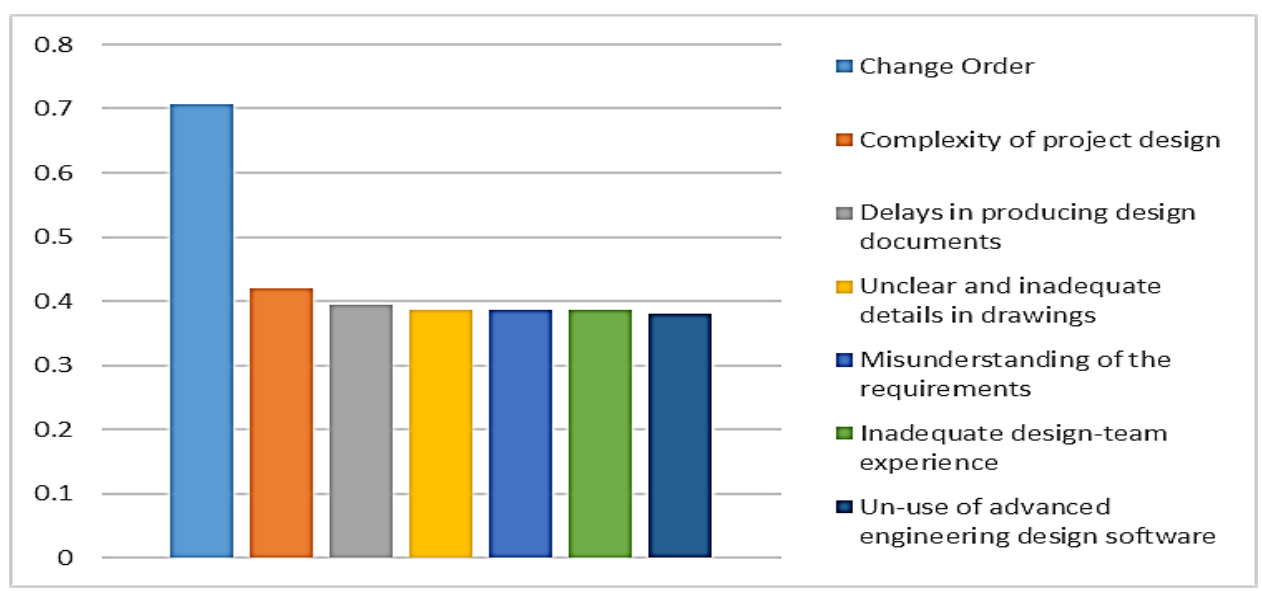

Figure 4-3. Natural/External Causes

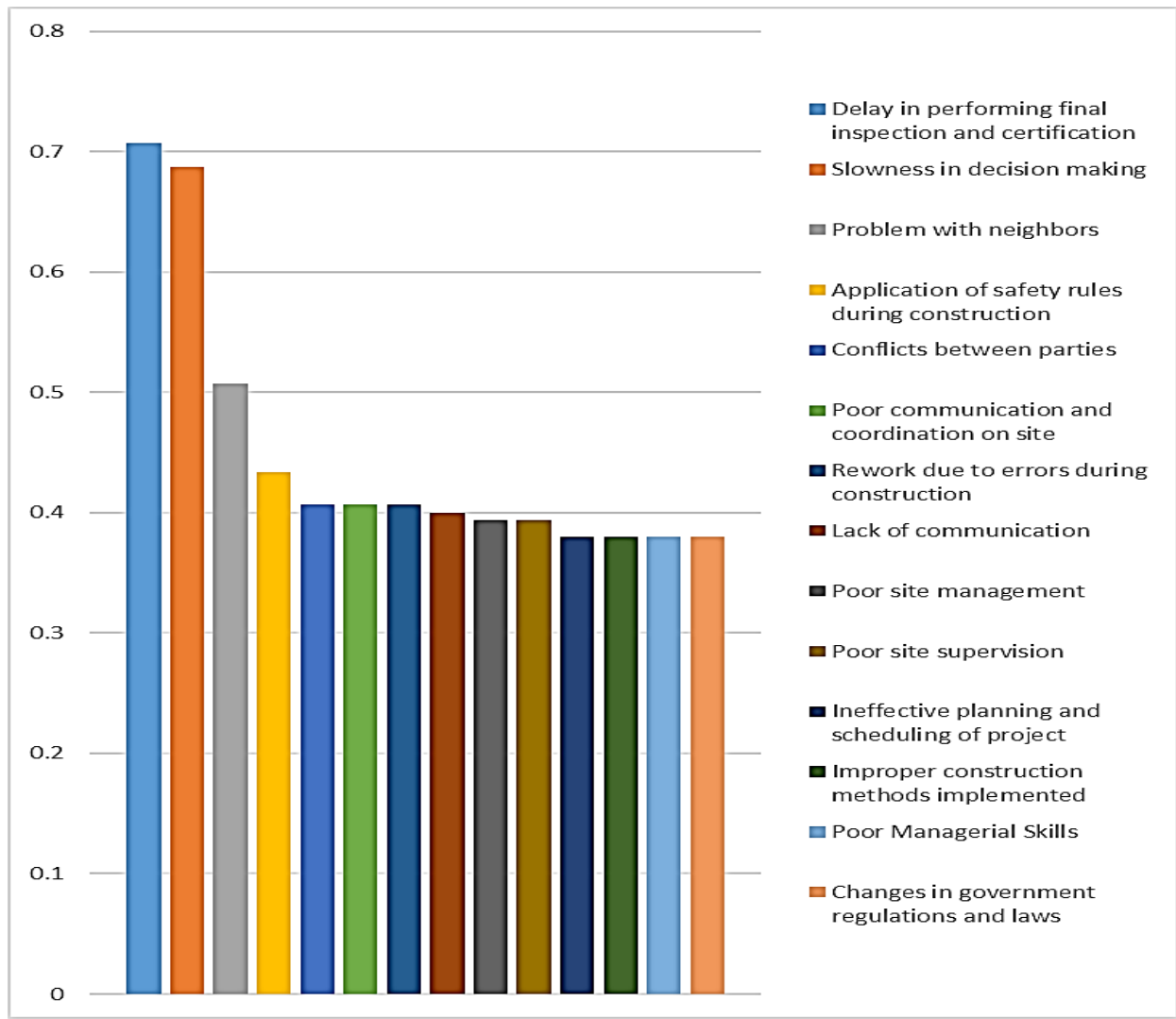

Figure 4-4. Management-related Causes 


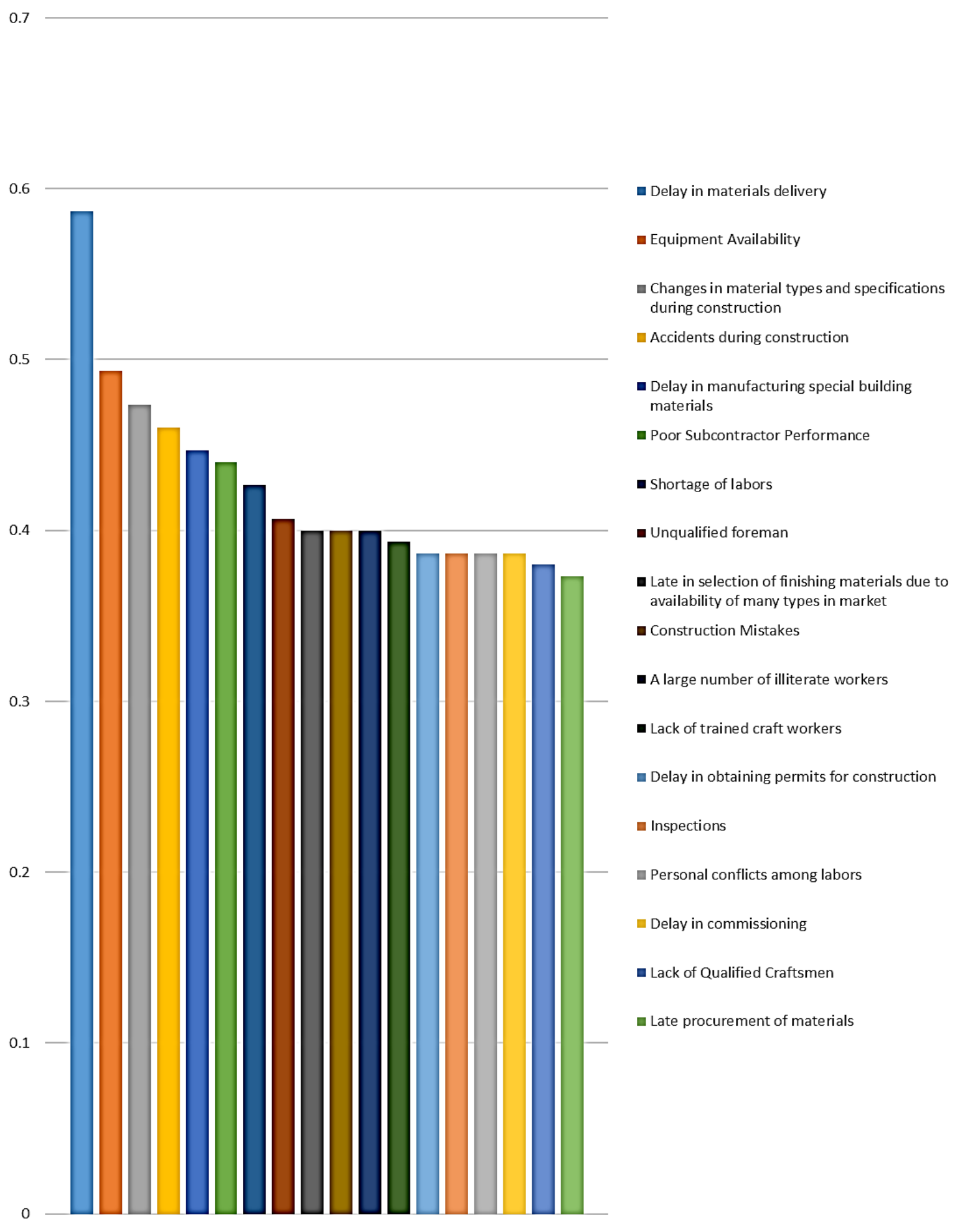

Figure 4-5. Construction-related Causes

Base on the ranking using RII, the top ten (3) most critical causes of delays are:

\begin{tabular}{|c|c|}
\hline No. & Delay Causes \\
\hline $\mathbf{1}$ & Due to Pandemic \\
\hline $\mathbf{2}$ & Rain effect on construction activities \\
\hline $\mathbf{3}$ & Change Order \\
\hline
\end{tabular}


The cause of delay due to the pandemic is excusable and noncompensable. The rain effect on construction activities is also excusable and non-compensable and change order is concurrent.

\section{CONCLUSION}

A project can be successfully completed if we are aware of and understand the causes of delays. By examining the factors that contribute to delays, we can address any issues that may arise as a result of the delay problem. According to the findings, the majority of delays are due to natural or external factors. The majority of DPWH-ADEO's projects have been delayed as a result of unexpected on-site problems caused by pandemic and weather effects. This implies that, while we should prioritize financial and management concerns, we should also consider weather and external factors.However, the outcomes of study must be evaluated in the context of a building project, considering the diverse geographical areas.Additionally, it would be beneficial for future research to incorporate additional variables and indicators. A more comprehensive examination of the factors will enable a better understanding of the causes and solutions to construction delays.

\section{REFERENCES}

1. Toor, Shamas-ur-Rehman \& Ogunlana, Stephen. (2008). Problems causing delays in major construction projects in Thailand. Construction Management \& Economics. 26. 395-408. 10.1080/01446190801905406.

2. Aedwin Regi Varghese \& Shibi Varghese. (2015). Analysis of delays in construction projects. International Journal of Engineering Research and General Science. ISSN 2091-2730

3. Ms.Yogita Honrao \& Prof.D.B.Desai (2015). Study of Delay in Execution of Infrastructure Projects Highway Construction. International Journal of Scientific and Research Publications, ISSN 22503153

4. Ashish Chandu Pawar, Sheetal D. Marawar\&Nikhil V. Bhalerao (2016). A Methodology for Ranking of Causes of Delay for Residential Projects. e-ISSN: 2395 -0056/p-ISSN: 2395-0072.

5. Nawab, Mohammad. (2016). Study of Delay Factors in Construction Projects. IARJSET. 10.17148/IARJSET.2016.3420.

6. Shabbab Al Hammadi\& M. Sadique Nawab (2016). Study of Delay Factors in Construction Projects. DOI: 10.17148/IARJSET.2016.3420

7. Famiyeh, Samuel \& Amoatey, Charles \& Adaku, Ebenezer \& Agbenohevi, Collins. (2017). Major causes of construction time and cost overruns: A case of selected educationalsector projects in Ghana. Journal of Engineering, Design and
Technology. 15. 181-198. 10.1108/JEDT-11-20150075.

8. Ghanim A. Bekr (2018). Study and Assessment of Causes and Effects of Delay in Large Public Construction Projects in Jordan. International Journal of Applied Engineering Research ISSN 0973-4562

9. Ruel R. Cabahug*, Mariell B. Arquita, Sheena Marie E. De La Torre, Michelle S. Valledor and Shiela Mae D. Olivares (2018). Factors Influencing the Delay of Road Construction Projects in Northern Mindanao, Philippines. Mindanao Journal of Science and Technology Vol.16 (2018) 187-197

10. Ludwig Rivera, Hilario Baguec, Jr. and Chunho Yeom (2020). A Study on Causes of Delay in Road Construction Projects across 25 Developing Countries. International School of Urban Sciences, University of Seoul, Seoul 151-742 